\title{
GAMBARAN CITRA TUBUH PADA WANITA DEWASA AWAL YANG MENGALAMI OBESITAS
}

\author{
M. Luthfi Fernando \\ Program Studi Psikologi Profesi Fakultas Psikologi, Universitas Airlangga \\ m.luthfi.fernando-2016@psikologi.unair.ac.id
}

\begin{abstract}
Abstrak. Citra tubuh adalah ide seseorang mengenai penampilannya dihadapan orang lain. Umumnya wanita memiliki perhatian lebih dalam menjaga penampilanya. Obesitas adalah suatu masalah yang ditakuti wanita dan dapat berdampak pada masalah psikologis dan kesehatan. Tujuan penelitian ini mengetahui gambaran citra tubuh pada wanita dewasa awal yang mengalami obesitas. Metode penelitian yang digunakan adalah pendekatan kualitatif studikasus dengan pada satu orang. Metode pengumpulan data menggunakan observasi, wawancara, dan kuesioner yang mengukur gambaran citra tubuh. Hasil penelitian menunjukkan subjek memiliki kebiasaan pola makan berlebihan dan kurang gerak tubuh sehingga memiliki dampak seperti gangguan psikososial: rasa rendah dan menarik diri, gangguan kesehatan: mudah lelah/mengantuk dan kesulitan keseimbangan. Adapun citra tubuhnya secara keseluruhan mengangggap fisik tidak menarik, kesulitan menyesuaikan diri, namun tidak melakukan usaha konsisten mengevaluasi penampilan sehingga disarankan melakukan konsultasi kesehatan dan psikologis.
\end{abstract}

Kata Kunci: Citra tubuh, Wanita Dewasa Awal, Obesitas

Abstract. Body image is someone's idea about his appearance before other people. Generally women have more attention in maintaining their appearance. Obesity is a problem that women fear and can have an impact on psychological and health problems. The purpose of this study is to describe body image in early adult women who are obese. The research method used was a qualitative approach to casestudy with one person. Methods of collecting data using observations, interviews, and questionnaires that measure the picture of body image. The results showed subjects had a habit of overeating and lacking gestures so that they had an impact such as psychosocial disorders: feeling of inferiority and withdrawal, health problems: fatiguel sleepiness and balance difficulties. The overall body image is physically unattractive, difficulty adjusting, but does not make a consistent effort to evaluate appearance so it is advisable to conduct health and psychological consultations.

Keywords: Body image, Early Adult Woman, Obesity 
Obesitas atau kegemukan merupakan suatu masalah yang ditakuti oleh para wanita. Papalia dan Olds (1995) mengatakan bahwa obesitas atau kegemukan terjadi jika individu mengkonsumsi kalori yang berlebihan dari yang mereka butuhkan. Secara umum obesitas adalah kelebihan berat badan yang jauh melebihi berat badan normal. Seseorang yang memiliki berat badan $20 \%$ lebih tinggi dari berat badannya yang normal dianggap mengalami obesitas. Wanita memiliki lemak tubuh yang lebih banyak dibandingkan pria, dimana perbandingan yang normal antara lemak tubuh dan berat badan adalah sekitar $25-30 \%$ bagi wanita dan $18-23 \%$ pada pria. Seorang wanita dikatakan obesitas apabila lemak pada tubuhnya lebih dari $30 \%$ dan pria memiliki lemak lebih 25\% (Wikipedia, 2007). Metode yang paling berguna dan banyak digunakan untuk mengukur tingkat obesitas dan overweight adalah Indeks Massa Tubuh (IMT) atau Body Mass Index (BMI). Berdasarkan World Health Oganization (WHO) seseorang dikatakan overweight jika hasil IMT sebesar 25,0 - 29,9, sedangkan seseorang dapat dikatakan obesitas jika hasil IMTnya sebesar 30,0 - 34,9 (Aru .W Sudoyo, 2006).

Beberapa penyebab dari terjadinya obesitas adalah dikarenakan terlalu sedikitnya aktifitas fisik dan juga disebabkan karena kebiasaan makan yang berlebihan. Program pengurangan berat badan yang menggunakan teknik modifikasi perilaku untuk membantu orang yang obesitas membuat perubahan dalam makanan dan latihan menunjukkan kesuksesan. Akan tetapi, faktor genetik dan lainnya yang sama sekali tidak berkaitan dengan kemauan dan pilihan gaya hidup membuat sebagian orang rawan terhadap obesitas. Termasuk pula diantara faktor ini regulasi metabolisme yang salah, ketidakmampuan mengenali sinyal tubuh akan rasa lapar dan kenyang, dan perkembangan jumlah sel lemak yang abnormal (Papalia, 2008).

Dampak buruk obesitas terhadap kesehatan, sangat berhubungan dengan berbagai macam penyakit yang serius, seperti tekanan darah tinggi, jantung, diabetes melitus, dan penyakit pernapasan. Dampak lain yang sering diabaikan adalah perasaan merasa dirinya berbeda atau dibedakan dari kelompoknya akan membuat individu dengan obesitas rentan terhadap berbagai masalah psikologis. Penelitian Daniel (1997) memperlihatkan bahwa ada hubungan yang sangat erat antara psikologis dengan obesitas pada wanita, terutama dalam bentuk depresi. Wanita obesitas yang dijauhi oleh teman-temannya memiliki kecenderungan untuk mengalami rasa putus asa yang besar. Hubungan antara obesitas dengan gejala psikologis merupakan suatu lingkaran yang tidak terputus. Seseorang yang mengalami obesitas akan mudah merasa tersisih atau tersinggung. Hal ini akan lebih parah bila ia mengalami kegagalan dalam pergaulan. Seseorang yang obesitas akan cenderung dicap sebagai orang yang susah bergaul dan mudah tersinggung. Orang yang obesitas akan mencap sebagian dari temannya sebagai orang yang suka mengolok-olok. Masalah psikologis yang paling umum didapatkan adalah cemas, ganggguan makan. Depresi pada obesitas dapat muncul karena pertentangan batin antara keinginan untuk memperoleh bentuk tubuh yang ideal dan kenyataan yang ada. Depresi terjadi sebagai akibat gangguan citra tubuh (sering berupa distorsi, bila melihat didepan cermin, seseorang tidak melihat tubuhnya sebagaimana adanya dalam realitas).

Bagi orang yang mengalami obesitas, masalah yang sering kali muncul adalah kepercayaan diri yang rendah. Hal ini sejalan denga hasil yang ditemukan di studi awal : “....untuk penampilan saya biasa nya sih jujur kadang-kadang itu minder, kadang-kadang ga percaya diri juga dihadapan orang, ya terkadang juga di ejek-ejek sama teman-teman" (Komunikasi Personal, 10 Apri 2018). Wanita yang menderita obesitas selalu dijadikan 
sebagai objek ejekan dan penampilan yang gemuk selalu di ejek dan dianggap sebagai hal yang lucu yang dapat membuat orang lain tertawa dan dianggap jelek (Dewi, 2004). Kenyataan ini dapat membuat penderita obesitas merasa dirinya sangat berbeda dan aneh dibandingkan dengan orang lain. Tubuh yang kurus bukan hanya dianggap menarik, tetapi tubuh yang gemuk dianggap sesuatu yang memalukan (Silverstein, Perdue, Petersor dan Kelly, 1986).

Orang yang obesitas memiliki kesulitan dalam hal perkembangan dan identitas (Sheshowsky,1983). Obesitas juga dapat menimbulkan masalah sosial bagi wanita (Kaplan, 1999). Dalam dunia sosial menunjukkan bahwa kecantikan dan ketertarikan merupakan hal yang membuat wanita dapat menarik perhatian lawan jenis dan lingkungan nya. Hal ini sesuai dengan tugas perkembangan dewasa awal yaitu memilih pasangan (Hurlock, 1980). Semua orang tentu saja ingin menampilkan sebuah tampilan fisik yang menarik, agar dapat menarik perhatian lawan jenisnya termasuk para wanita dewasa awal. Bagi seorang yang bentuk tubuhnya kurang ideal, sering sekali menolak kenyataan perubahan fisiknya sehingga mereka tampak mengasingkan diri karena merasa minder.

Agustiani (2006) mengatakan bahwa penilaian negatif individu pada dirinya akan menimbulkan perasaan tidak berdaya, artinya seseorang individu mempersepsi adanya kekurangan dalam segi fisik, tampilan yang tidak menyenangkan dan secara sosial tidak adekuat. Perasaan seperti ini tentu saja akan menghambat penyesuaian dirinya. Ketidakpuasan terhadap tubuh berhubungan dengan ketidak cocokan antara persepsi dan keinginan untuk memperoleh bentuk dan ukuran tubuh tertentu (Bosiet et al,.2006). Ketidak puasan ini yang pada akhirnya membuat wanita menjadi tidak percaya diri dan menganggap penampilannya sebagai sesuatu yang menakutkan.

Berdasarkan pemaparan diatas maka peneliti tertarik untuk meneliti bagaimana gambaran citra tubuh yang akan dilihat dari evaluasi penampilan, orientasi penampilan wanita dewasa awal yang mengalami obesitas sehingga nantinya hasil penelitian dapat memberikan manfaat referensi bagi wanita dewasa awal yang mengalami obesitas agar mendapatkan gambaran mengenai citra tubuhnya, kemudian bagi pihak keluarga agar dapat memberikan informasi tentang citra tubuh sehingga dapat membantu usaha evaluasi diri penyandang obesitas. Hal ini bertujuan agar wanita yang mengalami obesitas dapat menerima dan mengevaluasi keadaan tubuh atau fisiknya secara positif dan lebih baik.

\section{METODE}

Penelitian ini menggunakan pendekatan kualitatif perspektif studi kasus dengan variabel citra tubuh sebagai variabel penelitian yang ingin diteliti secara lebih mendalam. Penelitian kualitatif merupakan metode-metode untuk mencari jawaban atas suatu pertanyaan, dilakukan secara sistematik menggunakan seperangkat prosedur untuk menjawab pertanyaan, mengumpulkan fakta, menghasilkan suatu temuan yang tidak bisa ditetapkan sebelumnya, dan menghasilkan suatu temuan yang dapat dipakai melebihi batasan-batasan penelitian yang ada pada penelitian kuantitatif. Penelitian kualitatif digunakan untuk memahami suatu masalah penelitian dari sudut pandang/ perspektif populasi penelitian yang terlibat (Saryono, 2011). Perspektif studi kasus adalah studi 
yang mengekplorasi suatu masalah dengan batasan terperinci, memiliki pengambilan data yang mendalam, dan menyertakan berbagai informasi (Saryono, 2011). Dalam kaitannya dengan penelitian ini yaitu penulis ingin meneliti bagaimana gambaran citra tubuh wanita dewasa awal yang mengalami obesitas. Penulis ingin meneliti secara intensif dengan tujuan untuk memberikan gambaran-gambaran secara mendetail tentang gambaran citra tubuh yang dilihat dari evaluasi penampilan, orientasi penampilan wanita dewasa awal yang mengalami obesitas. Adapun tempat lokasi penelitian ini dilakukan dibanjarmasin.

Subjek dalam penelitian kualitatif ini disebut dengan subjek. Jumlah subjek yang terlibat dalam penelitian ini sebanyak satu orang, didapatkan dengan menggunakan purposif sampling yang memiliki kriteria; usia berkisar antara 21 sampai dengan 30 tahun, mengalami obesitas dengan IMT (Indeks masa tubuh) minimal sebesar 30,0 - 34,9. Pengumpulan data dilakukan dengan metode wawancara mendalam (in depth interview). Prosedur wawancara dilakukan dengan mengacu pada panduan wawancara yang dibuat oleh peneliti berdasarkan demensi citra tubuh oleh Cash (2004). Panduan wawancara yang dibuat adalah dalam bentuk pertanyaan terbuka dimana subjek penelitian dapat menjawab bebas semua pertanyaan yang diajukan oleh peneliti. Wawancara yang dilakukan bersifat semi terstruktur yang berarti bahwa peneliti tidak hanya menanyakan hal-hal yang ada di panduan wawancara saja tetapi pertanyaan lain dapat diajukan oleh peneliti mengikuti respons yang diberikan oleh subjek untuk dapat menggali data lebih dalam. Penelitian ini juga menggunakan observasi untuk melihat secara langsung bagaimana subjek menggambarkan citra tubuhnya dalam sehari-hari, ditambah dengan tes informal (kuisioner yang telah di uji validitas dan reliabilitasnya untuk mengukur citra tubuh sehingga dapat menambah informasi selain dari sumber utama yaitu wawancara. Adapun tehnik analsis data yang digunakan dalam penelitian ini adalah dengan mencari dan menyusun secara sistematis data yang diperoleh dari hasil wawancara, observasi, dan tes informal, sehingga kemudian diorganisasikan datanya lalu dijabarkan kedalam unit-unit demensi citra tubuh kemudian dilakukan sintesa dengan hasil temuan untuk dipilih mana yang penting dan yang akan dipelajari dan dibuat kesimpulan secara keseluruhan dari hasil penelitian.

\section{HASIL}

A. Hasil Asesmen

1. Identitas Subjek/Identitas Kasus
a. Nama
b. Jenis Kelamin
c. Usia
d. Berat badan
e. Tinggi Badan
f. Status dalam Keluarga

: MA

: Perempuan

: 23 Tahun

$: 105 \mathrm{Kg}$

: $170 \mathrm{Cm}$

: Anak ke-2 dari 3 saudara

2. Riwayat Kasus

a. Riwayat Perkembangan dan Kesehatan

Selama ini belum pernah/ belum terdiagnosa penyakit berat. Namun sudah terlihat dampak seperti gangguan saluran pernafasan terbukti dari hasil wawancara yang subjek ungkapkan bahwa subjek sering mengantuk dan menurut signifikan others terkadang subjek tidur dengan mengorok. 
b. Riwayat Keluarga dan Tempat Tinggal

Tempat tinggal Desa Dahai, Kecamatan Paringin, KAB. Balangan dan Sekarang tinggal di banjarbaru sendirian dan kos terpisah dari orang tua untuk kuliah, subjek anak ke 2 dari 3 saudara dan menjadi satu-satu nya anggota keluarga yang mengalami obesitass.

\section{Hasil Wawancara}

Berdasarkan hasil tiga kali wawancara yang telah dilakukan dengan subjek sebanyak 2x pada tanggal 24 April 2018 pukul 16.30-17.00, 31 April 2018 pukul 12.00 -12.20 dan pada signifikan others sebanyak 1x pada tanggal 27 April 2018, 12.00-12.20, didapatkan hasil bahwa subjek bernama MA yang berusia 23 tahun menyatakan dia mengukur evaluasi dari penampilan dan keseluruhan bentuk tubuh nya adalah tidak menarik. Sebenarnya subjek memiliki keinginan untuk memiliki penampilan yang menarik, tapi kelebihan berat badaan nya menyulitkan subjek mencari pakaian yang sesuai dengan bentuk tubuhnya, sehingga kepercayaan diri subjek di hadapan orang lain rendah, subjek merasa minder dan malu di hadapan orang-orang yang tidak dikenalnya tetapi untuk dihadapan teman-teman nya subjek mengungkapkan kepercyaan dirinya tidak terganggu karena sudah adanya penerimaan terhadap dirinya oleh teman-temannya.

Untuk perhatian individu terhadap penampilannya dan usaha yang dilakukan untuk memperbaiki dan meningkatkan penampilannya subjek menyatakan bahwa lebih suka memakai pakaian yang longgar karena menurut nya jika memakai pakaian yang ngepas ditubuhnya akan menampakkan bentuk tubuh gemuknya, tapi subjek masih merasa tidak cocok dengan pakaian yang biasa dia gunakan karena menurutnya pakaian yang biasa digunakannya masih agak kekecilan/ngepas ditubuh dan tidak longgar, hal ini senada dengan yg di ungkapkan signifikan others pada saat wawancara bahwa subjek biasa masih memakai pakaian yang ngepas karena subjek kesulitan mencari pakaian yang sesuai dengan bentuk tubuhnya dan subjek juga mengungkapkan halnya demikian, hal ini juga yang menyebabkan subjek tidak dapat mengikuti fashion wanita zaman sekarang agar dapat memperbaiki penampilannya karena menurutnya pakaian yang modis zaman sekarang tidak menyediakan bentuk ukuran besar biasanya hanya sampai seperti ukuran M saja, subjek juga mengungkapkan bahwa subjek tidak dapat mengikuti model hijab zaman sekarang karena subjek mudah kepanasan karena badannya yang besar, subjek juga menyatakan bahwa subjek malas untuk berolahraga agar menguruskan badannya ataupun untuk kesehatannya walaupun sudah sering mendapat dorongan dari teman-temannya, dan menurut signifikan others subjek pernah melakukan usaha berolahraga, seperti lari pagi setiap hari minggu, bermain hula-hup dengan rutin, pernah ikut yoga,bahkan meminum obat pelangsing namun semuanya usaha gagal begitu saja akibat subjek tidak konsisten terhadap usahanya dan sekarang subjek hanya ingin dikamarnya saja setiap harinya, tapi menurut signifikan others dalam waktu-waktu terakhir subjek pernah mengatakan ingin membeli matras untuk yoga lagi.

Untuk mengukur kepuasan subjek terhadap bagian tubuh spesifik dan penampilan secara keseluruhan, subjek menyatakan bahwa tidak ada spesifik nya bagian apa 
saja yang harus di perbaiki tapi semuanya harus di perbaiki, karena menurut subjek seluruh bentuk tubuh nya adalah besar sehingga seluruh bentuk tubuh nya harus dikecilkan/diperbaiki. Secara keseluruhan subjek mengungkapkan dia tidak puas dengan bentuk tubuhnya sekarang karena tubuh nya terlalu besar sehingga subjek tidak dapat mengikuti trend wanita zaman sekarang yang berpenampilan modis, subjek juga merasa tidak ada yang dapat dia banggakan dari bagian tubuh nya bahkan subjek merasa terganggu karena susahnya mencari baju dan susah nya menaiki tangga ke lantai 3 saat perkuliahan, selain itu subjek tidak bisa menaiki kendaraan karena sulit menahan keseimbangan akibat berat badan hal menyebabkan dirinya harus berjalan kaki setiap hari kekampus dan tidak bisa kemana-mana kecuali ada teman yang mempunyai mobil yang bisa membawanya, subjek juga sering merasa mudah capek dan mengantuk sehingga sangat terganggu.

Untuk mengukur kecemasan dan kewaspadaan subjek terhadap berat badan, seperti melakukan diet dan mebatasi pola makan subjek menyatakan bahwa subjek kesulitan mengontrol porsi makan karena sudah terbiasa sejak SD,SMP,SMA bahkan sampai saat ini makan dengan porsi yang banyak, subjek mengungkapkan bahwa pernah melakukan diet namun kadang-kadang selalu gagal mengontrol pola makan dan akhirnya dietnya gagal bahkan menyebabkan subjek lebih gemuk lagi. Tetapi menurut signifikan others subjek dapat mengontol pola makan nya ketika malam hari, sejak waktu terakhir hingga sekarang subjek mengontrol pola makan nya di malam hari dan menolak makanan yang signifikan others jika dimalam hari, dan untuk siang hari tidak ada kontrol terhadap makanan oleh subjek. Subjek mengungkapkan dalam hal makanan dia memiliki prinsip " buat apa disia-siakan maknan yang enak, maknan enak itu harus di nikmati" sehingga subjek selalu memakan makanan yang dia punya dan sering nyemil. Menurut signifikan others subjek tidak suka maknan-maknan manis seperti coklat,kue dan lain-lain bahkan susu, tetapi subjek selalu memakan cemilan yang berminyak seperti gorengan, keripik-keripik dan lainya tanpa batas tertentu. Subjek menyatakan bahwa sebenarnya ada kepedulian dan keinginan membatasi pola makan yang sehat dengan mengimbangi olahraga karena kewaspadaan nya takut akan penyakitpenyakit seperti jantung,koleterol,darah tinggi akibat obesitas namun subjek kesulitan menghilangkan kebiasaan makan berlebihannya sehingga kesulitan melakukan diet.

Untuk mengukur bagaimana subjek mempersepsikan dan menilai berat badannya, peneliti menanyakan bagaimana tanggapan subjek jika orang lain mengatakan subjek menarik, subjek mengungkapkan bahwa tidak percaya karena kenyataan nya dia tidak menarik dan gemuk, bahkan menurut subjek orang lain yang tidak dia kenal memandangnya seperti mengejek. Menurut subjek tubuh ideal wanita itu seperti artis-artis korea, seperti Park Shin Hye dan Ola ramlan.

Adapun faktor-faktor yang mempengaruhi citra tubuh pada subjek yang dapat di gali diwawancara seperti media massa, signifikan others menyatakan subjek menyukai film-film korea sehingga mempengaruhi persepsi bentuk tubuh ideal/kurus wanita itu seperti artis korea. Selanjutnya faktor keluarga subjek mengungkapkan orang tua nya sering melakukan usaha dulu nya seperti menyuruh diet, mebelikan obat pengurus badan dan hasilnya nihil sehingga sekarang orang 
tua subjek menyerah, tetapi subjek sering di banding-bandingkan dengan kakak nya karena badan obesitasnya yang membuat diri subjek menjadi pemalas dirumah, subjek juga mengungkapkan dia sering di ejek gendut oleh kakak nya bahkan di marahi seperti ketika harus membonceng subjek naik motor karena kesulitan membawa subjek. Dan yang terkahir adalah faktor hubungan interpersonal subjek menyatakan sering merasa minder dengan teman-teman nya dan membandingbandingkan tubuh nya dengan teman-teman nya yang kurus, subjek mngungkapkan ada rasa keinginan seperti teman-teman nya memiliki tubuh kurus dan ideal.

\section{Hasil Observasi}

Berdasarkan hasil observasi yang dilakukan pada tanggal 24 April 2018, pada pukul 09.30-12.30 didapat hasil bahwa untuk dalam orientasi appearance subjek dalam berpenampilan memakai pakaian yang masih kurang cocok untuk tubuhnya karena pakaian yang di pakai subjek terlalu ngepas ditubuhnya sehingga terlihat badan nya yang besar, subjek juga berpenampilan biasa saja tanpa ada usaha memperbaiki penampilannya seperti berakaian trendy layak nya wanita zaman sekarang, ataupun memakai pakaian yang longgar agar menutupi bentuk tubuh nya yang sangat gemuk. Sedangkan, subjek masih terlihat selama observasi seperti memakan cemilan-cemilan kecil dan memakan gorengan yang berminyak, subjek juga makan dengan porsi yang sangat banyak bahkan dari pagi hari awal observasi hingga sore hari setelah wawancara pertama subjek sudah makan 3 kali dengan porsi yang banyak.

Kemudian Observasi selanjutnya tanggal 27 April 2018, pada pukul 10.30-15.30 dilakukan oleh signifikan others yaitu sahabat subjek yang bertempat tinggal satu kost dengan subjek dan satu kelas kuliah dengan subjek, hasil observasi signifikan others subjek menyatakan bahwa untuk dalam orientasi appearance subjek, subjek kuliah dengan memakai pakaian yang masih belum cocok karena agak kekecilan, pakaian yang digunakan subjek juga biasa-biasa saja tanpa model-model tertentu, subjek belum melakukan usaha mengenakan pakaian yang longgar agar menutupi bentuk tubuh besar nya karena subjek kesulitan mencari pakaian yang sesuai dengan bentuk tubuh nya. Sedangkan untuk pada subjek menurut hasil observasi signifikan others subjek tidak ada membatassi dalam hal makanan ataupun cemilan, subjek juga makan dengan porsi yang melebihi orang normal.

Observasi ke 2 yang menjadi observassi terakhir dilakukan peneliti dilaksanakan pada tanggal 31 April 2018, pada pukul 08.00-12.20. Adapun hasil yang didapatkan adalah dalam orientasi appearance, subjek masih memakai pakaian yang kurang cocok ditubuh nya karena terlalu kecil sehingga terlihat lemak berlebih di bagian-bagian tubuhnya, subjek belum melakukan usaha menutupi bentuk tubuh besarnya dengan memakai pakaia yang longgar, subjek di observasi ke 2 ini juga masih berpenampilan biasa saja. Dan untuk overweight preocupation subjek masih senang memakan cemilan yang dia punya, subjek juga belum ada membatasi porsi makan nya, subjek dari pagi hingga siang hari makan 2x dengan porsi yang banyak.

\section{Hasil Kuesioner}


Dalam penelitian ini, peneliti menggunakan kuesioner/ angket dengan skala likert yang terdiri dari lima dimensi gambaran tubuh, yaitu evaluasi penampilan, orientasi penampilan, kepuasan terhadap bagian tubuh, kecemasan menjadi gemuk dan pengkategorian ukuran tubuh. Skala ini terdiri dari 4 pilihan jawaban yaitu Sangat Sesuai (SS), Sesuai (S), Tidak Sesuai (TS), dan Sangat Tidak Sesuai (STS). Skala disajikan dalam bentuk pertanyaan favorable (mendukung) dan unfavorable (tidak mendukung). Nilai pilihan bergerak dari 1-4, bobot penilaian untuk pernyataan favorable yaitu $\mathrm{SS}=4, \mathrm{~S}=3, \mathrm{TS}=2$, $\mathrm{STS}=1$, sedangkan untuk bobot pernyataan unfavorable yaitu $\mathrm{SS}=1, \mathrm{~S}=2, \mathrm{TS}=3, \mathrm{STS}=4$. Adapun angket yang digunakan dalam penelitian ini adalah angket dari penelitian sebelumnya oleh Kinanti Indika, 2010, Universitas Sumatera Utara.

a. Validitas

Untuk mengetahui apakah skala psikologi mampu menghasilkan data yang akurat sesuai dengan tujuan ukurnya, diperlukan suatu pengujian validitas (Azwar, 2004). Angket ini validitas isi tesnya sudah di tentukan melalui pendapat profesional dalam proses telaah soal. Pendapat profesional diperoleh dengan cara berkonsultasi dengan dosen pembimbing.

b. Daya beda aitem

Kemampuan aitem dalam membedakan antara subjek yang memiliki atribut yang diukur dan yang tidak. Selain itu, indeks daya beda aitem merupakan indikator keselarasan atau konsistensi antara fungsi aitem dengan fungsi skala secara keseluruhan yang dikenal dengan konsistensi aitem total. Pengujian daya diskriminasi aitem menghendaki dilakukannya komputasi korelasi antara distribusi skor skala itu sendiri. Komputasi ini akan menghasilkan koefisien korelasi aitem total (r) yang dikenal dengan sebutan parameter daya beda aitem. Kriteria pemilihan aitem berdasarkan korelasi aitem menggunakan batasan $r=$ 0,275 . Pengujian daya diskriminasi aitem pada skala sikap dilakukan dengan mengkorelasikan antara skor tiap aitem dengan skor total, dengan menggunakan teknik korelasi Pearson Product Moment dengan bantuan program SPSS versi 15.

c. Reliabilitas alat ukur

Menurut Azwar (2004), reliabilitas mengacu kepada konsistensi atau keterpercayaan hasil ukur adalah untuk mencari dan mengetahui sejauh mana hasil pengukuran dapat dipercaya. Prosedur pengujian reliabilitas yang digunakan dalam angket ini adalah koefisien reliabilitas alpha. Data untuk menghitung koefisien reliabilitas alpha diperoleh melalui penyajian satu bentuk skala yang dikenakan hanya sekali saja pada sekelompok responden (single-trial administratio). Reliabilitas dinyatakan oleh koefisien reliabilitas (r) yang angkanya berada dalam rentang 0 sampai dengan 1 . koefisien reliabilitas semakin mendekati angka 1 menandakan semakin tinggi reliabilitas. Sebaliknya, koefisien yang semakin mendekati angka 0 berarti semakin rendah reliabilitas yang dimiliki. Teknik koefisien alpha untuk menguji reliabilitas alat ukut dihitung dengan bantuan program SPSS versi 15. Hasil uji coba alat ukur di olah melalui tiga kali pengujian agar memperoleh reliabilitas yang memenuhi standar ukur dan indeks daya beda aitem di atas 0,275. 
Tabel 1. Hasil Skor (Kuesioner Citra Tubuh)

\begin{tabular}{|l|l|l|l|l|l|l|}
\hline NO & Demensi & Favorable & Unfavorabel & Nilai F & $\begin{array}{l}\text { Nilai } \\
\text { UF }\end{array}$ & $\begin{array}{l}\text { Total } \\
\text { Nilai }\end{array}$ \\
\hline $\mathbf{1 .}$ & $\begin{array}{l}\text { Evaluasi } \\
\text { Penampilan }\end{array}$ & $1,6,10,22$ & $3,8,13,17,27$ & $2,2,2,2$ & $2,2,2,1,1$ & $\mathbf{1 6}$ \\
\hline $\mathbf{2 .}$ & $\begin{array}{l}\text { Orientasi } \\
\text { Penampilan }\end{array}$ & 4,9 & 2,51 & 3,2 & 2,2 & $\mathbf{9}$ \\
\hline $\mathbf{3 .}$ & $\begin{array}{l}\text { Kepuasan Bagian } \\
\text { Tubuh }\end{array}$ & $5,19,23,34$ & $16,28,40$ & $3,3,4,2$ & $3,3,1$ & $\mathbf{1 9}$ \\
\hline $\mathbf{4 .}$ & $\begin{array}{l}\text { Kecemasan } \\
\text { Menjadi Gemuk }\end{array}$ & $30,45,53$ & 12,37 & $3,3,2$ & 2,3 & $\mathbf{1 3}$ \\
\hline $\mathbf{5 .}$ & $\begin{array}{l}\text { Pengkategorisasi } \\
\text { an Ukuran Tubuh }\end{array}$ & $33,43,47,49,55$, & 32,6 & $\begin{array}{l}2,3,2,2,3 \\
, 2\end{array}$ & 3,3 & $\mathbf{2 0}$ \\
\hline & Total & $\mathbf{1 9}$ & $\mathbf{1 4}$ & $\mathbf{4 5}$ & $\mathbf{2 9}$ & $\mathbf{7 7}$ \\
\hline
\end{tabular}

Hasil kuesioner pengukuran citra tubuh yang digunakan dalam penelitian ini memiliki norma sebagai berikut. Gambaran citra tubuh secara keseluruhan dikatakan negatif jika $\mathrm{X}$ $\leq 77$, netral jika $77<X<90$ dan positif jika $X \geq 90$. Adapun norma perdimensi dari 5 dimensi citra tubuh yaitu:

1. Dimensi evaluasi penampilan negatif jika $X \leq 15$, netral jika $15<X<29$, positif jika $\mathrm{X} \geq 29$

2. Dimensi orentasi penampilan negatif jika $X \leq 7$, netral jika $7<X<15$, positif jika $X \geq$ 15.

3. Dimensi kepuasan bagian tubuh negatif jika $X \leq 12$, netral jika $12<X<22$, positif jika $X \geq 22$.

4. Dimensi kecemasan menjadi gemuk negatif jika $X \leq 9$, netral jika $9<X<21$, positif jika $X \geq 21$.

5. Dimensi pengkategorisasian ukuran tubuh negatif jika $X \leq 12$, netral jika $12<X<$ 27, positif jika $X \geq 27$ (Kinanti Indika, 2010).

Berdasarkan hasil kuesioner yang didapatkan pada subjek dalam penelitian ini, subjek masih tergolong dalam kategori memiliki citra tubuh yang masih berada pada area netral 77 dan memiliki gambaran yang juga netral pada 5 area dimensi citra tubuh yang ada.

\section{DISKUSI}

Papalia dan Olds (1995) mengatakan bahwa obesitas atau kegemukan terjadi jika individu mengkonsumsi kalori yang berlebihan dari yang mereka butuhkan. Untuk mengukur lemak tubuh secara langsung sangat sulit dan sebagai pengukur pengganti dipakai body mass index (BMI) atau indeks massa tubuh (IMT) untuk menentukan berta badan yang lebih dan obesitas pada seseorang (Aru W. Sudoyo, 2006). Subjek berinisial MA dan berjenis kelamin perempuan memiliki tinggi badan $170 \mathrm{Cm}$, dengan berat badan $105 \mathrm{Kg}$. Jika di hitung dengan IMT maka di dapatkan hasil 36,3 yang artinya subjek sudah memasuki klasifikasi obesitas II. Adapun faktor-faktor yang mempengaruhi subjek menjadi obesitas seperti kebiasaan pola makan yang berlebihan, sesuai yang di jelaskan subjek dan signifikan others bahwa subjek memiliki porsi makan yang berlebihan/ sangat banyak bahkan tanpa ada batasan makan yang jelas dalam sehari dan hal tersebut sudah menjadi kebiasaan sejak subjek masih SD hingga sekarang. Dari hasil observasi yang 
dilakukan peneliti dan signifikan others juga menyatakan bahwa subjek memiliki porsi makan yang banyak dan tidak ada batasan dalam makan di kesehariannya, kemudia subjek juga kurang gerak atau olahraga, dalam hasil wawancara bahwa subjek menyatakan bahwa subjek malas untuk berolahraga dan sering malas-malasan. Untuk sekarang subjek sudah menerima dampak obesitas yang yang terjadi pada dirinya seperti gangguan psiko-sosial : Rasa rendah diri, depresif dan menarik diri dari lingkungan. Hal ini dikarenakan anak obesitas seringkali menjadi bahan hinaan teman sepermainan dan teman sekolah. Dapat pula karena ketidakmampuan untuk melaksanaan suatu tugas/kegiatan terutama olahraga akibat adanya hambatan pergerakan oleh kegemukannya. Dari hasil wawancara subjek menyatakan sering minder dan malu karena tubuh nya yang gemuk, subjek juga menungkapkan sering jaddi bahan ejekan orangorang. Pertumbuhan fisik/linier yang lebih cepat dan usia tulang yang lebih lanjut dibanding usia biologisnya. Orang yang memiliki berat badan yang berlebihan seperti subjek sudah pasti memiliki usia tulang yang lebih lanjut dari usia biologisnya. Gangguan pernafasan : Sering terserang infeksi saluran nafas, tidur ngorok, kadangkadang terjadi opnea sewaktu tidur, sering ngantuk siang hari. Bila gangguan sangat berat disebut sebagai sindrom Pickwickian, yaitu adanya hipoventilasi alveolar. Ditemukan dalam hasil wawancara subjek menyatakan sering mengantuk dan menurut signifikan others subjek terkadang mendengkur ketika tidur. Obesitas juga akan berelanjut sampai dewasa, terutama bila obesitas mulai pada pra-pubertal. Obesitas yang terjadi pada subjek dimulai sejak subjek berada di bangku SD hingga sekarang berusia 23 tahun. Hurlock (1999) mengatakan bahwa masa dewasa awal dimulai pada umur 18 tahun sampai umur 40 tahun, saat perubahan-perubahan fisik dan psikologis yang menyertai berkurangnya kemampuan reproduktif. Jika obesitas ini dibiarkan saja, bisa saja kemungkinan akan memberikan dampak kesehatan yang tidak baik kedepannya untuk subjek seperti masalah ortopedi , gangguan endokrin, penyakit degenaratif dan penyakit metabolik (tekanan darah tinggi, jantung, diabetes melitus).

Menurut kamus psikologi (Chaplin, 2005) citra tubuh adalah ide seseorang mengenai penampilannya di hadapan orang (bagi) orang lain. Papalia, Olds, dan Feldman (2001) menyatakan bahwa citra tubuh merupakan gambaran dan evaluasi mengenai penampilan seseorang. Dacey \& Kenny (2001) menyatakan bahwa citra tubuh adalah keyakinan seseorang akan penampilan mereka di hadapan orang lain. Dari hasil tes informal (Anket Citra Tubuh) yang di berikan kepada subjek dinyatakan bahwa citra tubuh pada subjek adalah netral, namun netral bukan berarti aman-aman saja nilai netral yag di dapatkan subjek pada tes informal nyaris berada di klasifikasi citra tubuh yang negatif yaitu berada persis di batas antara netral dan negatif (Skor 77), jika dibiarkan saja tanpa ada usaha perbaikan citra tubuh dapat menjadi mediator potensial antara obesitas dan tekanan psikologis (Michael A. Friedman b, Karen Jaffe).

Untuk pengukuran gambaran tubuh dalam penelitian ini menggunakan dimensi-dimensi pada alat ukur yang dikemukakan oleh Cash dkk, (dalam Seawell \& Danorf-Burg, 2005). Cash (2004) mengemukakan adanya lima dimensi citra tubuh, yaitu Appearance Evaluation (Evaluasi penampilan), yaitu mengukur evaluasi dari penampilan dan keseluruhan tubuh, apakah menarik atau tidak menarik serta memuaskan dan tidak memuaskan. Menurut subjek dari hasil wawancara, evaluasi dari penampilan dan keseluruhan bentuk tubuh nya adalah tidak menarik. Menurut nya kelebihan berat badannya membuat dirinya tampak tidak menarik. Appearance Orientation (Orientasi 
penampilan), yaitu perhatian individu terhadap penampilan dirinya dan usaha yang dilakukan untuk memperbaiki dan meningkatkan penampilan dirinya. Menurut hasil wawancara subjek menyatakan bahwa lebih suka memakai pakaian yang longgar karena menurut nya jika memakai pakaian yang ngepas ditubuhnya akan menampakkan bentuk tubuh gemuknya, tapi subjek masih merasa tidak cocok dengan pakaian yang biasa dia gunakan karena menurutnya pakaian yang biasa digunakannya masih agak kekecilan/ngepas ditubuh dan tidak longgar, sesuai yang dipatkan peneliti dan signifikan others dalam hasil oservassi bahwa subjek masih memakai pakian yang kurang cocok dan tidak longgar ditubuhnya, hal ini senada dengan yg di ungkapkan signifikan others pada saat wawancara bahwa subjek biasa masih memakai pakaian yang ngepas karena subjek kesulitan mencari pakaian yang sesuai dengan bentuk tubuhnya dan subjek juga mengungkapkan halnya demikian, hal ini juga yang menyebabkan subjek tidak dapat mengikuti fashion wanita zaman sekarang agar dapat memperbaiki penampilannya karena menurutnya pakaian yang modis zaman sekarang tidak menyediakan bentuk ukuran besar biasanya hanya sampai seperti ukuran M saja, subjek juga mengungkapkan bahwa subjek tidak dapat mengikuti model hijab zaman sekarang karena subjek mudah kepanasan karena badannya yang besar, subjek juga menyatakan bahwa subjek malas untuk berolahraga agar menguruskan badannya ataupun untuk kesehatannya walaupun sudah sering mendapat dorongan dari teman-temannya, dan menurut signifikan others subjek pernah ingin berolahraga lari pagi setiap hari minggu, bermain hula-hup dengan rutin, pernah ikut yoga,bahkan meminum obat pelangsing dan semuanya gagal begitu saja dan sekarang subjek hanya ingin dikamarnya saja setiap harinya, tapi menurut signifikan others dalam waktu-waktu terakhir subjek pernah mengatakan ingin membeli matras untuk yoga lagi. Body Area Satisfaction (Kepuasan terhadap bagian tubuh), yaitu mengukur kepuasan individu terhadap bagian tubuh secara spesifik, seperti wajah, rambut, tubuh bagian bawah (pantat, paha, pinggul, kaki), tubuh bagian tengah (pinggang, perut), tubuh bagian atas (dada, bahu, lengan), dan penampilan secara keseluruhan.

Menurut hasil wawancara subjek menyatakan bahwa tidak ada spesifik nya bagian apa saja yang harus di perbaiki tapi semuanya bagian tubuhnya harus di perbaiki, karena menurut subjek seluruh bentuk tubuh nya adalah besar sehingga seluruh bentuk tubuh nya harus dikecilkan/di perbaiki. Secara keseluruhan subjek mengungkapkan dia tidak puas dengan bentuk tubuhnya sekarang karena tubuh nya terlalu besar sehingga subjek tidak dapat mengikuti trend wanita zaman sekarang yang berpenampilan modis, subjek juga merasa tidak ada yang dapat dia banggakan dari bagian tubuh nya bahkan subjek merasa terganggu karena susahnya mencari baju dan susah nya menaiki tangga ke lantai 3 saat perkuliahan, tidak bisa menaiki kendaraan karena sulit menahan kesseimbangan akibat berat badan menyebabkan dirinya harus berjalan kaki setiap hari kekampus dan tidak bisa kemana-mana kecuali ada temen yang mempunyai mobil yang bisa membawanya, subjek juga sering merasa mudah capek dan mengantuk sehingga sangat terganggu. Overweight Preocupation (Kecemasan menjadi gemuk), yaitu mengukur kecemasan terhadap kegemukan, kewaspadan individu terhadap berat badan, kecenderungan melakukan diet untuk menurunkan berat badan dan membatasi pola makan. Subjek menyatakan bahwa subjek kesulitan megotrol porsi makan karena sudah terbiasa sejak SD,SMP,SMA bahkan hingga kuliah sekarang makan dengan porsi yang banyak, subjek mengungkapkan bahwa pernah melakukan diet namun kadang-kadang selalu gagal mengontrol pola makan dan akhirnya dietnya gagal bahkan menyebabkan 
subjek lebih gemuk lagi. Hal ini sesuai dengan hasil observasi yang dilakukan peneliti dan signifikan others bahwa subjek selalu makan dengan porsi yang banyak dan tanpa ada batasan. Tetapi menurut signifikan others subjek dapat mengontol pola makan nya ketika malam hari, sejak waktu terakhir hingga sekarang subjek mengontrol pola makan nya dimalam hari dan menolak makanan yang signifikan others jika dimalam hari, dan untuk siang hari tidak ada kontrol terhadap makanan oleh subjek. Subjek mengungkapkan dalam hal makanan dia memiliki prinsip " buat apa disia-siakan maknan yang enak, maknan enak itu harus di nikmati" sehingga subjek selalu memakan makanan yang ada dia punya dan sering nyemil. Menurut signifikan others subjek tidak suka maknan-maknan manis seperti coklat,kue dan lain-lain bahkan susu, tetapi subjek selalu memakan cemilan yang berminyak seperti gorengan, keripik-keripik dan lainya tanpa batas tertentu. Dari hasil observasi juga didapatkan hasil bahwa subjek selalu memakan cemilan-cemilan yang dia punya. Subjek menyatakan bahwa sebenarnya ada kepedulian dan keinginan membatasi pola makan yang sehat dengan mengimbangi olahraga karena kewaspadaan nya takut akan penyakit-penyakit seperti jantung,koleterol,darah tinggi akibat obesitas namun subjek kesulitan menghilangkan kebiasaan nya makan sesukanya sehingga kesulitan melakukan diet. Self-Classified Weight (Pengkategorian ukuran tubuh), yaitu mengukur bagaimana individu mempersepsi dan menilai berat badannya, dari sangat kurus sampai sangat gemuk. Untuk mengukur bagaimana subjek mempresepsikan dan menilai berat badannya, peneliti menanyakan bagaimana tanggapan subjek jika orang lain mengatakan subjek menarik, subjek mengungkapkan bahwa tidak percaya karena kenyataan nya dia tidak menarik dan gemuk, bahkan menurut subjek orang lain yang tidak dia kenal memandangnya seperti mengejek. Menurut subjek tubuh kurus ideal untuk wanita itu seperti artis-artis korea, seperti Park Shin Hye dan Ola ramlan.

Adapun faktor-faktor yang mempengaruhi citra tubuh pada subjek seperti jenis kelamin, Chase (2001) menyatakan bahwa jenis kelamin adalah faktor paling penting dalam perkembangan citra tubuh seseorang. Beberapa penelitian yang sudah dilakukan menyatakan bahwa wanita lebih negatif memandang citra tubuh dibandingkan pria (Cash \& Brown, 1989: Davidson \& McCabe, 2005: Demarest \& Allen, 2000: Furnaham \& Greaves, 1994:, Jenelli, 1993: Rozin \& Fallon, 1988 dalam Hubley \& Quinlan, 2005). Usia, Pada tahap perkembangan dewasa awal hal yang umum dilakukan oleh wanita, khususnya mahasiswi dalam menjaga penampilanya adalah dengan pengaturan pola makan. Dijelaskan pada wawancara bahwa ada keinginan subjek menjaga penampilannya dengan membatasi pola makan, dan olahraga agar terlihat menarik, namun masih kesulitan melakukan nya secara konsisten. Media Massa. Tiggemann (dalam Cash \& Pruzinsky, 2002) mengatakan bahwa media yang muncul dimana-mana memberikan gambaran ideal mengenai figur perempuan dan laki-laki yang dapat mempengaruhi gambaran tubuh seseorang. Tiggemann (dalam Cash \&purzinsky, 2002). Diwawancara subjek menyatakan wanita yang ideal adalah seperti artis-artis korea, hal ini disebabkan subjek menyenangi film film korea menurut hasil wawancara signifikan others. Keluarga, Menurut teori social leraning, orang tua merupakan model yang paling penting dalam proses sosialisasi sehingga mempengaruhi gambaran tubuh anak anaknya melalui modeling, feedback dan instruksi. Ikeda and Narworski (dalam Cash dan Purzinsky, 2002) menyatakan bahwa komentar yang dibuat orang tua dan anggota keluarga mempunyai pengaruh yang besar dalam gambaran tubuh anak- anak. Didapatkan dari hasil wawancara subjek mengungkapkan bahwa orang tua nya banyak melakukan 
intruksi seperti melakukan diet, memberikan obat pengurus badan dan berolahraga kepada subjek, bahkan banyak komentar orang tua subjek terhadap bentuk tubuh subjek seperti di banding-bandingkan dengan kakak nya yang tidak obesitas. Hubungan interpersonal, hubungan interpersonal membuat seseorang cenderung membandingkan diri dengan orang lain dan feedback yang diterima mempengaruhi konsep diri termasuk mempengaruhi bagaimana perasaan terhadap penampilan fisik. Dijelaskan pada hasil wawancara subjek sering membandingkan dirinya dengan teman-teman nya dan menimbulkan keinginan subjek agar memiliki tubuh kurus dan ideal seperti temantemannya hal ini juga yang meyebabkan subjek merasa minder dan kadang-kadang malu dengan teman-temannya.

Hurlock (1999) mengatakan bahwa masa dewasa awal dimulai pada umur 18 tahun sampai umur 40 tahun, saat perubahan-perubahan fisik dan psikologis yang menyertai berkurangnya kemampuan reproduktif. Kebanyakan individu menganggap dirinya telah menyelesaikan perkembangan fisik pada masa remaja mereka, namun faktanya bahwa tubuh terus mengalami perubahan sampai mati, sehingga mahasiswi yang mengalami ketidakpuasaan pada penampilan fisiknya akan menghabiskan banyak waktu dan pikiran untuk memperbaiki penampilan mereka. Namun disini ditemukan bahwa subjek masih belum banyak menghabiskan waktu dan berpikir untuk memperbaiki penampilannya, karena putus asa akibat kegagalan nya melakukan usaha menguruskan badannya selama ini seperti tidak ada efek dari obat pengurus, pola makan yang tidak dapat dijaga konsisten, olahraga yang tidak dapat konsisten. 


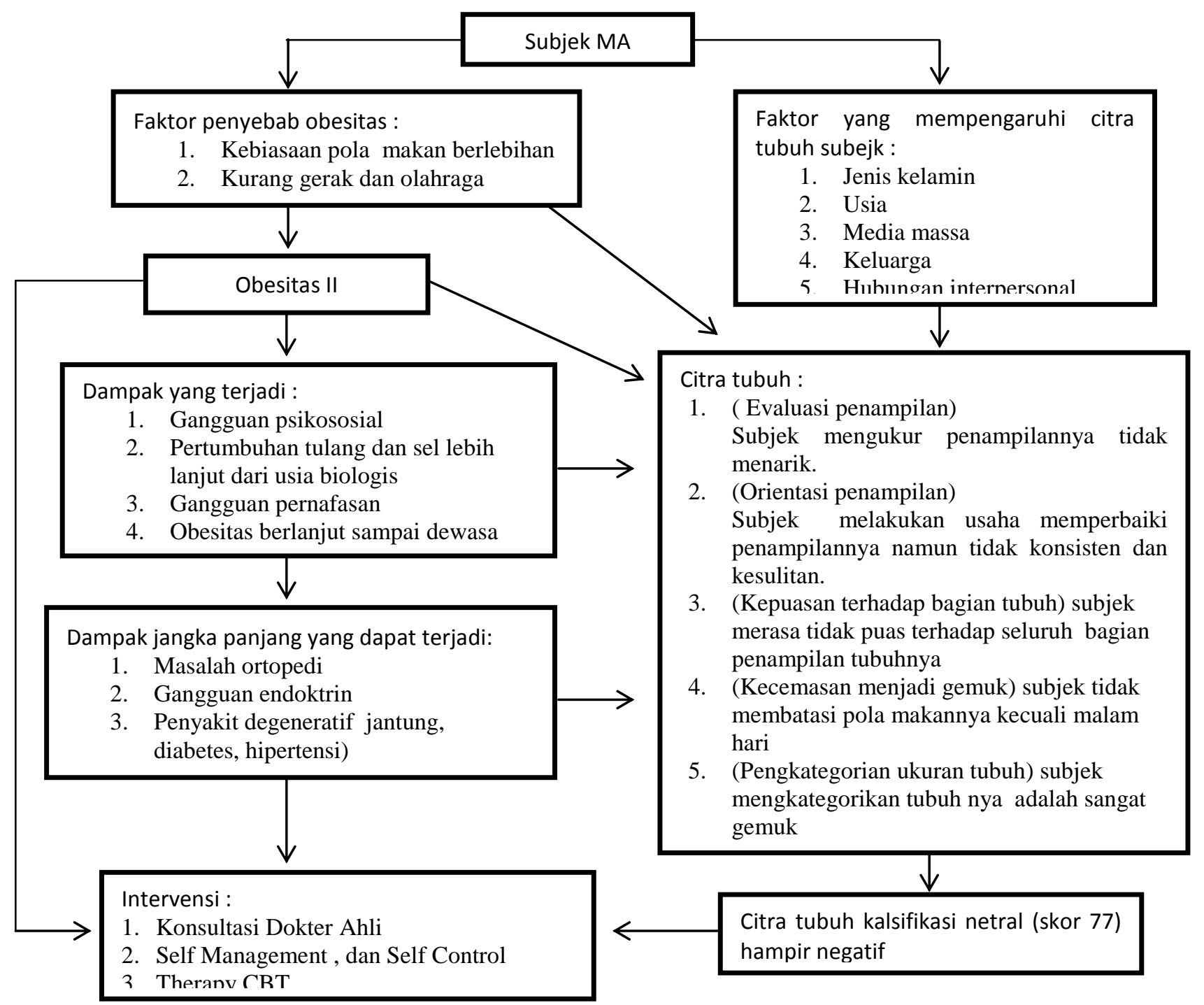

Gambar 1. Psikodinamika/Bagan Masalah

Adapun citra tubuh yang digambarkan subjek secara keseluruhan adalah subjek menganggap orentasi penampilannya secara fisik tidak menarik sama sekali, ia mengalami kesulitan menyesuaikan diri, namun cenderung masih tidak melakukan usaha konsisten mengevaluasi penampilan. Tata laksana utama kegemukan terdiri dari diet dan latihan fisik. Program diet dapat menghasilkan penurunan berat badan dalam jangka pendek, tetapi mempertahankan penurunan berat badan ini seringkali merupakan hal yang sulit dan memerlukan latihan dan diet makanan berenergi rendah sebagai bagian dari gaya hidup yang bersifat permanen. Karena masalah utama pada subjek dalam menurunkan berat badannya adalah tidak konsisten melakukan usaha menguruskan badannya dengan minum obat, olahraga, dan diet.

Maka saran intervensi yang diberikan adalah :

1. Konsultasi Dokter Ahli

Subjek di anjurkan untuk melakukan konsultasi pada dokter ahli karena dengan konsultasi dokter ahli subjek dapat di periksa secara keseluruhan kesehatan 
fisik/biologis nya agar diketahui gangguan fisik/biologis nya yang sudah terjadi dan kemungkinan jangka panjangnya agar diberikan intervensi pengobatan, program diet dan program pencegahan gangguan jangka panjang.

\section{Terapi Psikologis}

a. Self Management dan Self Control

Teknik perubahan perilaku self management merupakan salah satu dari penerapan teori modifikasi perilaku dan merupakan gabungan teori behavioristik dan teori kognitif sosial. Hal ini merupakan hal baru dalam membantu konseli menyelesaikan masalah karena didalam tekhnik ini menekankan pada konseli untuk mengubah tingkah laku yang dianggap merugikan yang sebelumnya menekankan pada bantuan orang lain. Tujuan dari self management pada subjek adalah agar dapat mengembangan perilaku yang lebih adatif . dengan proses pengubahan tingkah laku dengan satu atau lebih strategi melalui pengelolaan tingkah laku internal dan eksternal individu, agar dapat meberi penerimaan individu terhadap program perubahan perilaku menjadi syarat yang mendasar untuk menumbuhkan motivasi individu untuk melakukan usaha menguruskan badannya, disini subjek juga berpartisipasi untuk menjadi agen perubahan perilakunya, juga agar subjek dapat menggeneralisasi dan tetap mempertahankan hasil akhir usahanya menurunkan berat badan dengan jalan mendorong individu untuk menerima tanggung jawab menjalankan strategi mengurud-skan badannya dalam kehidupan sehari-hari, subjek juga di ajarkan menggunakan ketrampilan menangani masalah makan nya dan rasa malasnya berolahraga.

Menurut kamus psikologi (Chaplin, 2002), definisi kontrol diri atau self control adalah kemampuan individu untuk mengarahkan tingkah lakunya sendiri dan kemampuan untuk menekan atau menghambat dorongan yang ada. Goldfried dan Merbaum, mendefinisikan kontrol diri sebagai suatu kemampuan untuk menyusun, membimbing, mengatur dan mengarahkan bentuk perilaku yang dapat membawa individu kearah konsekuensi positif.

Kontrol diri merupakan satu potensi yang dapat dikembangkan dan digunakan individu selama proses-proses dalam kehidupan, termasuk dalam menghadapi kondisi yang terdapat dilingkungan yang berada disekitarnya, para ahli berpendapat bahwa kontrol diri dapat digunakan sebagai suatu intervensi yang bersifat preventif selain dapat mereduksi efek-efek psikologis yang negative dari stressor-stresor lingkungan. Disamping itu kontrol diri memiliki makna sebagai suatu kecakapan individu dalam kepekaan membaca situasi diri dan lingkungannya serta kemampuan untuk mengontrol dan mengelola faktor-faktor perilaku sesuai dengan situasi dan kondisi untuk menampilkan diri dalam melakukan sosialisasi sehingga tujuan dari kontrol diri pada subjek agar subjek dapat lebih dapat mengelola dan mengontrol dirinya terhadap menampilkan dirinya dalam sosialisasi hidupnya agar dapat mereduksi efek-efek negatif dari stressor lingkungannya.

b. Dengan menggunakan CBT ( Cognitif Behavioral Therapy). Terapi kognitifperilaku (CBT) merupakan terapi yang mendasarkan pada teori kognitif perilaku yang menekankan pikiran, perasaan dan perilaku, Menurut teori ini psikopatologi terjadi bila terdapat ketidak sesuaian antara tuntutan-tuntutan 
lingkungan dengan kapasitas adaptif individu. Teori ini sangat efektif karena penderita telah memiliki kesadaran bahwa mereka memiliki berat badan yang berlebih, pola makan yang tidak normal. Namun mereka tidak berdaya untuk mengendalikan dorongan makan pada saat perut terasa lapar sehingga diperlukan penyadaran pikiran dan perasaan agar subjek mampu mengenali dan kemudian mengevaluasi atau rnengubah cara berfikir, keyakinan dan perasaannya (mengenali diri sendiri dan lingkungan) yang salah, dapat mengubah perilaku maladaptive dengan cara mempelajari ketrampilan pengendalian diri dan staregi pemecahan masalah yang efektif. Misalnya subjek diminta untuk melakukan latihan-latihan menantang pikiran yang negatif seperti membandingkan gambar-gambar wanita atau pria yang mempunyai tubuh gemuk dan yang mempunyai tubuh ramping dengan tujuan mernbangkitkán persepsi yang berhubungan dengan body image nya. Hasil kajian yang dilakukan oleh American Dietetic Association (ADA) antara Juli 2007dan Maret 2008 menunjukkan bahwa, penerapan teori perilaku dan teori perilaku berbasis kognitif (CBT) sangat efektif untuk memfasilitasi klien dalam modifikasi diet, target penurunan berat badan (Iis Rosita, dkk. (2011).

\section{SIMPULAN DAN IMPLIKASI}

Berdasarkan hasil uraian tersebut, dapat disimpulkan bahwa citra diri subjek MA yang mengalami obesitas II adalah netral dengan skor 77 namun skor ini bukan berarti amanaman saja tetapi juga perlu di perbaiki bahkan hampir mendekati negatif. Subjek menganggap orentasi penampilannya secara fisik tidak menarik sama sekali, ia mengalami kesulitan menyesuaikan diri, namun cenderung masih tidak melakukan usaha konsisten mengevaluasi penampilan. Tata laksana utama kegemukan terdiri dari diet dan latihan fisik. Program diet dapat menghasilkan penurunan berat badan dalam jangka pendek, tetapi mempertahankan penurunan berat badan ini seringkali merupakan hal yang sulit dan memerlukan latihan dan diet makanan berenergi rendah sebagai bagian dari gaya hidup yang bersifat permanen. Karena masalah utama pada subjek dalam menurunkan berat badannya adalah tidak konsisten melakukan usaha menguruskan badannya dengan minum obat, olahraga, dan diet.

Adapun saran-saran yang diberikan untuk subjek, di anjurkan untuk melakukan konsultasi pada dokter ahli karena dengan konsultasi dokter ahli subjek dapat di periksa secara keseluruhan kesehatan fisik/biologis nya agar diketahui gangguan fisik/biologis nya yang sudah terjadi dan kemungkinan jangka panjangnya agar diberikan intervensi pengobatan, program diet dan program pencegahan gangguan jangka panjang. Subjek juga di anjurkan agar melakukan psikoterapi CBT dan Self Management, Self Control dengan Psikolog guna membantu masalahnya dalam melakukan usaha menguruskan badan dengan konsisten.

Untuk masyarakat luas, dapat sebagai referensi bagi wanita dewasa awal/mahasiswi yang mengalami obesitas agar mendapatkan gambaran mengenai citra tubuh., juga sebagai referensi bagi keluarga, agar dapat memberikan informasi tentang citra tubuh. Hal ini bertujuan orang yang mengalami obesitas dapat menerima keadaan tubuh atau fisiknya secara positif atau baik. 
Untuk peneliti selanjutnya, diharapkan dapat menyempurnakan hasil temuan ini dengan membandingkan pada beberapa subjek serupa yang lebih banyak dan mungkin dapat menambah teori-teori yang ada agara lebih banyak referensi yang digunakan, sehingga mudah dalam melakukan analisis dan pembahasan.

\section{REFRENSI}

Alwisol. (2009). Psikologi Kepribadian Edisi Revisi. Malang: UMM Press.

Basow, A. Susan. (1992). Garden: Sereoyupes and Roles (3rd). California: Books Publishing Company

Bigner, J.J. (1994). Parent Child Relations: an Introduction to Parenting (4th ed).

Chaplin, C.P. (2005). Kamus Lengkap Psikologi, Terj. Kartini Kartono, Jakarta

Chas, F. Thomas. (1999). Body image, development, deviance, and change. New York: The Guilford Press.

Chas, F. Thomas. (2004). Body image: past, present, and future. Journal of Psychology, Old Dominion University : Norfolk, Virginia, VA 23529, USA

Dacey, J and Kenny, M. (1997). Adolescent Development (2nd). USA: Brown and Benchmark Publishers

Dacey, J., \& Kenny, Maureen. (2001). Adolescent development (2nd ed). USA: Brown \& Benchmark Publisher.

Dewi, Amanah. (2004). Perbedaan Kepercayaan Diri antara Remaja Pria dan Wanita yang Mengalami Obesitas pada Siswa/i SMAN di kota Rantauparapat. Universitas Medan Area

Friedmann, Kellie.E., Simona K. Reichmann (2002). Body Image Partially Mediates the Relationship between Obesity and Psychological Distress. Vol.10 :33-41.

Harisson, Kristen (2003). Television Viewer's Ideal Body Proportions: The Curvaceously Thin women Sex Roles: A Journal of Research. Plenum Publishing Coorporation: Illinois.

Hurlock, B. Elizabeth. (1999). Psikologi Perkembangan: Suatu Pendekatan Sepanjang Rentang Kehidupan. Jakarta: Penerbit Erlangga.

Hurlock, E. (1980). Psikologi Perkembangan: Suatu Rentang Kehidupan. Jakarta: Erlangga.

Iis Rosita, dkk. (2011). Konseling Gizi Transtheoritical Model dalam Mengubah Perilaku Makan dan Aktivitas Fisik pada Remaja Overweight dan Obesitas. Jurnal Fakultas Kedokteran, Universitas Padjajaran: Bandung 
Indika, Kinanti. (2010). Gambaran Citra Tubuh Pada Remaja Yang Obesitas. Fakultas Psikologi: Universitas Sumatera Utara.

Indonesian Nutrion Network, 2005

Leliana. Yuliana. (2004). Konsep Diri Remaja Putri yang Mengalami Obesitas.Artikel Fakultas Psikologi, Universitas Gunadharma: Depok

Mengenali Obesitas (2007). Online http//www.wikipedia.com

Michael A. Friedman b, Karen Jaffe (2007). Understanding the relationship between obesity and positive and negative affect: The role of psychosocial mechanisms. Department of Sociology and Center for Demography of Health and Aging, University of Wisconsin, United States.

Monks, F.J., Knoers, A.M.P., \& Haditono, S.R. (2001). Psikologi perkembangan: pengantar dalam Berbagai Bagiannya. Yogyakarta: Gadjah Mada University Press

Nasar SS. (1995). Obesitas pada anak aspek klinis dan pencegahannya. Dalam: Samsudin, Nasar SS, Sjarif Dr, Penyunting Naskah Lengkap PKB-IKA XXXV. Masalah Gizi Ganda dan Tumbuh Kembang Anak. Jakata: Bina Rupa Aksara. H. 68-81.

Papalia, D. E., Olds, S. W., \& Feldman, R.D. (2008). Human Development (Psikologi Perkembangan Edisi ke 9). Jakarta: Kencana

Papalia, E. Diane., Olds, W.S., Feldman D.R. (2001). Human development (8th ed). New York: McGraw-Hill,Inc.

Ramayulis, Rita. (2007). 17 Alternatif untuk Langsing. Jakarta: Gramedia

Rupang, Indra.dkk (2014). Hubungan Tingkat Kepercayaan Diri Dengan Obesitas Pada Siswa SMA Rex Mundi Manado. Jurnal Bagian Psikologi Fakultas Kedokteran Universitas Sam Ratulangi: Manado.

Santrock, J. W. (2008). Life span development (Perkembangan sepanjang hidup). Jilid 1. Jakarta: Erlangga.Sarafio, Edward P, (1998). Health Psychology : Biopsychosocial Interaction (3rd edition). Ney York: John Wiley and Sons. Inc

Saryono. 2011. Metodologi Penelitian Kualitatif dalam Bidang Kesehatan. Yogyakarta: Nuha Medika.

Schlundt, D.J and johnson, A. (1990). Eating Disorder: Assessment and Teratment. Boston: Allyn and Bacon

Sugiyono. (2010). Memahami Penelitian Kualitatif. Bandung: Alfabeta. 